\title{
Long-term tebuthiuron content of grasses and shrubs on semiarid rangelands
}

\author{
T.N. JOHNSEN, JR. AND H.L. MORTON
}

\section{Abstract}

Perennial plants collected from 5 north-central Arizona semiarid locations were assayed for tebuthiuron $\{\mathbf{N}-5$-(1,1-dimethylethyl-1,3,4-thiadiazol-2-yl- $N, N^{\prime}$-dimethylurea $\}$ and its metabolites using gas chromatography with flame photometric detection. Tebuthiuron was applied at rates ranging from 0.9 to $6.7 \mathrm{~kg}$ active ingredient (a.i.)/ha in 1975 through 1979. Plants were harvested in 1980 through 1986, 2 to 11 years after applications. Tebuthiuron was detected in sideoats [Bouteloua curtipendula (Michx.) Torr.] and blue grama [B. gracilis (H.B.K.) Lag. ex Griffiths] 10 years after application of $6.7 \mathrm{~kg} / \mathrm{ha}$. Metabolites of tebuthiuron were detected in blue grama 11 years after applications of $2.2,4.5$, and $6.7 \mathrm{~kg} / \mathrm{ha}$. The ratios of tebuthiuron to metabolites varied widely. The highest concentrations of tebuthiuron plus metabolites were $25 \mu \mathrm{g} / \mathrm{g}$ in blue grama 10 years after application of $4.5 \mathrm{~kg} / \mathrm{ha}$, and 21 and $23 \mu \mathrm{g} / \mathrm{g}$ in sideoats grama 9 and 10 years, respectively, after application of $6.7 \mathrm{~kg} / \mathrm{ha}$. Only these 3 samples of 120 samples assayed exceeded the legal limit of $20 \mu \mathrm{g} / \mathrm{g}$ of tebuthiuron plus metabolites in forage plants. No samples from plots treated with 4.0 or less $\mathrm{kg} / \mathrm{ha}$ exceeded $10 \mu \mathrm{g} / \mathrm{g}$ of tebuthiuron plus metabolites, and only $10 \%$ of them exceeded $5 \mu \mathrm{g} / \mathrm{g}$.

Key Words: Bouteloua curtipendula, B. gracilis, herbicide metabolites, B. eriopoda, herbicide residues

Tebuthiuron \{ $N$-[5-(1,1-dimethylethyl)-1,3,4-thiadiazol-2-yl]- $N$. $N^{\prime}$ dimethylurea\} is a persistent, soil applied herbicide used to control brush and weeds on rangelands and along rights-of-way (Scifres et al. 1979, Pettit 1979, Meyer et al. 1983, Clary et al. 1985a, Herbel et al. 1985, McDaniel and Balliette 1986). Forage production and quality often increase following tebuthiuron treatments (Scifres and Mutz 1978, Scifres et al. 1983, Bovey et al. 1984, Masters and Scifres 1984, Whitson and Alley 1984, Herbel et al. 1985). This forage may be preferentially grazed over that on untreated areas (Scifres et al. 1983, Biondini et al. 1986). The Environmental Protection Agency specifies that no more than 20 $\mu \mathrm{g} / \mathrm{g}$ of tebuthiuron plus its metabolites may occur in forage and hay, and that treated grasses are not to be cut for hay or grazed by lactating dairy cows for 2 years after application.

Tebuthiuron is absorbed by plant roots and accumulated in the top growth (Baur and Bovey 1975, Steinert and Stritzke 1977), and may be returned to soils from decomposing litter (Garcia and Lee 1979). The amount of tebuthiuron absorbed by plants increases with the rate of treatment (Martin and Morton 1981). Plants metabolize tebuthiuron (Loh et al. 1978, Martin and Morton 1981, McNeil et al. 1984). But metabolism may be slow. Only tebuthiuron was found in plants 24 hours after tebuthiuron was absorbed through the roots (Steinert and Stritzke 1977).

Tebuthiuron concentrations in grasses were less than $1 \mu \mathrm{g} / \mathrm{g}$ during the initial 6 months after treatment with tebuthiuron pellets in south Texas (Bovey et al. 1978). But in other field tests, grasses averaged $4.4,2.2,0.1$, and $0.9 \mu \mathrm{g} / \mathrm{g}$ of tebuthiuron plus metabolites during the first, second, third, and fourth years after application,

\footnotetext{
Authors are research agronomist and plant physiologist, USDA-ARS, Aridland Watershed Management Research Unit, 2000 East Allen Road, Tucson, Arizona 85719

The authors thank Richard Martin and Jennifer Ruyle, who did the assays, and Charles Braun, Bobby Buck, and Rey Madrigal, who helped make the field collections.

Manuscript accepted 31 May 1990.
}

respectively, and no samples exceeded $20 \mu \mathrm{g} / \mathrm{g}$ (Elanco Products 1983). The highest concentration of tebuthiuron plus metabolites detected in samples from Arizona and Northern Mexico was 18.4 $\mu \mathrm{g} / \mathrm{g}$ in blue grama [Bouteloua gracilis (H.B.K.) Lag ex Griffiths] 12 months after application of $1.5 \mathrm{~kg} /$ ha (Ibarra 1984); however, concentrations of tebuthiuron and metabolites fluctuated widely. Grasses usually contained more metabolites than tebuthiuron during a 30-month period after applications (Ibarra 1984).

In greenhouse studies resistant grasses accumulated up to 20 $\mu \mathrm{g} / \mathrm{g}$ of tebuthiuron plus metabolites, while metabolizing as much as $50 \%$ of the tebuthiuron. But a susceptible shrub accumulated as much as $200 \mu \mathrm{g} / \mathrm{g}$ of tebuthiuron plus metabolite, metabolizing less than 20\% of the tebuthiuron (Martin and Morton 1981).

Plants should accumulate tebuthiuron or its metabolites whenever tebuthiuron is present in the soil. Under semiarid conditions tebuthiuron was detected in soils during the initial 4 years after application (Emmerich et al. 1984, Ibarra and Morton 1984, Sosebee et al. 1979, Clary et al. 1985b), and, in addition, has been found in soils as long as 11 years after application (Johnsen and Morton 1989). So tebuthiuron could be in current year plant tissue as long as 11 years after application.

Because tebuthiuron-treated forage plants may be selectively grazed, it is important to know how long after treatment tebuthiuron and its metabolites can be detected in plants growing on treated areas. No studies of tebuthiuron and or its metabolites in plants have been reported for periods longer than 4 years. Therefore, the objective of this study was to determine how much and how long tebuthiuron and its metabolites could be detected in common range plants after tebuthiuron application on semiarid southwestern pinyon-juniper rangelands.

\section{Methods and Materials}

\section{Study Locations}

The study was conducted at 5 north-central Arizona locations: Brushy Mountain, Drake, and Rio Verde were north of Prescott, and Indian Flat and Red Mountain were north of Flagstaff (Table 1). Indian Flat was the highest, coolest, and wettest location, while Drake and Rio Verde were the lowest, warmest, and driest locations (Table 1). Rainfall at all locations was bimodal, usually falling as local thunderstorms in summer and as widespread rain or snow storms in winter. Rainfall was not recorded on site during the study, but records from nearby weather stations were reviewed to identify wet and dry periods. Annual rainfall in 1978, 1980, and 1983 was wetter than normal; in $1976,1979,1981,1985$, and 1986 it was drier than normal; and in 1977, 1982, and 1984 it was normal.

Soils were Mollisols except for the Vertisol at Drake (Table 1). Soils were shallow to moderately deep and were underlain by basalt and cinders, except that Barkerville soils were underlain by granite. The Lynx and Tajo soils contain caliche.

Pinyon-juniper was the dominant vegetation at all locations (Table 1). One-seed juniper [Juniperus monosperma (Engelm.) Sarg.] dominated at Indian Flat and Red Mountain while Utah juniper [ $J$. osteosperma (Torr.) Little] dominated at the older locations. Perennial grasses were the main understory plants; black grama [Bouteloua eriopoda (Torr.) Torr.] and sideoats grama [ $B$. curtipendula (Michx.) Torr.] predominated at the lower eleva- 


\begin{tabular}{|c|c|c|c|c|c|}
\hline \multirow[b]{2}{*}{ Location } & \multirow[b]{2}{*}{ Elevation } & \multirow{2}{*}{$\begin{array}{l}\text { Annual } \\
\text { rainfall }\end{array}$} & \multicolumn{2}{|c|}{ Soil } & \multirow[b]{2}{*}{ Major plants } \\
\hline & & & Series, texture & Classification & \\
\hline $\begin{array}{l}\text { Brushy } \\
\text { Mountain }\end{array}$ & $\underset{1,520}{\mathrm{~m}}$ & $\begin{array}{l}\mathrm{mm} \\
380\end{array}$ & $\begin{array}{l}\text { Barkerville, } \\
\text { sandy loam }\end{array}$ & $\begin{array}{l}\text { Loamy, mixed mesic } \\
\text { shallow } \\
\text { Udorthentic Haplustolls } \\
\text { Mollisols }\end{array}$ & $\begin{array}{l}\text { Turbinella } \\
\text { oak } \\
\text { Utah juniper Pinyon }\end{array}$ \\
\hline Drake & 1,400 & 330 & $\begin{array}{l}\text { Springerville } \\
\text { clay } \\
\text { Tajo, loam }\end{array}$ & $\begin{array}{l}\text { Fine, montmorillonitic, } \\
\text { mesic } \\
\text { Typic Chromusterts } \\
\text { Vertisols } \\
\text { Fine-loamy, mixed } \\
\text { mesic } \\
\text { Petrocalcic Paleustolls } \\
\text { Mollisols }\end{array}$ & $\begin{array}{l}\text { Utah juniper } \\
\text { Blue grama } \\
\text { Sideoats grama } \\
\text { Black grama } \\
\text { Utah juniper } \\
\text { Black grama } \\
\text { Blue grama } \\
\text { Sideoats grama }\end{array}$ \\
\hline $\begin{array}{l}\text { Indian } \\
\text { Flat }\end{array}$ & 2,220 & 430 & Thunderbird, clay loam & $\begin{array}{l}\text { Fine, montmorillonitic, mesic } \\
\text { Aridic Argiustolls } \\
\text { Mollisols }\end{array}$ & $\begin{array}{l}\text { One-seed juniper } \\
\text { Pinyon } \\
\text { Blue grama }\end{array}$ \\
\hline $\begin{array}{l}\text { Red } \\
\text { Mountain }\end{array}$ & 1,950 & 310 & Thunderbird clay loam & $\begin{array}{l}\text { Fine, montmorillonitic, mesic } \\
\text { Aridic Argiustolls } \\
\text { Mollisols }\end{array}$ & $\begin{array}{l}\text { One-seed juniper } \\
\text { Pinyon } \\
\text { Blue grama }\end{array}$ \\
\hline Rio Verde & 1,290 & 340 & $\begin{array}{l}\text { Barkerville, } \\
\text { sandy loam }\end{array}$ & $\begin{array}{l}\text { Loamy, mixed, mesic } \\
\text { shallow } \\
\text { Udorthentic Haplustolls } \\
\text { Mollisols }\end{array}$ & $\begin{array}{l}\text { Utah juniper } \\
\text { Pinyon } \\
\text { Turbinella oak } \\
\text { Sideoats grama } \\
\text { Black grama }\end{array}$ \\
\hline & & & Lynx, loam & $\begin{array}{l}\text { Fine-loamy, mixed } \\
\text { mesic } \\
\text { Cumulic Haplustolls } \\
\text { Mollisols }\end{array}$ & $\begin{array}{l}\text { Utah juniper } \\
\text { Pinyon } \\
\text { Sideoats grama } \\
\text { Blue grama }\end{array}$ \\
\hline
\end{tabular}

tions. Blue grama predominated at the higher locations, but was found at all locations.

\section{Treatments}

Application rates used were experimental, mostly equal to or more than the maximum $2.2 \mathrm{~kg}$ a.i. $/$ ha recommended for rangeland use, but less than amounts used on non-crop lands or right-ofways. Pelleted tebuthiuron containing 16,32 , and $47 \%$ active ingredient (a.i.) by weight were applied to points in $2.74-$ by $2.74-\mathrm{m}$ grid patterns at equivalent rates of $2.2,4.5$, and $6.7 \mathrm{~kg} \mathrm{a.i.} / \mathrm{ha}$, respectively, on nonreplicated $16.4-$ by $19.2-\mathrm{m}$ plots at Drake in April 1975.

Pelleted tebuthiuron containing $10 \%$ a.i. by weight was hand broadcast on 5- by $10-\mathrm{m}$ plots in randomized complete block studies with 2 replications at Drake, Indian Flat, and Red Mountain. At Drake, tebuthiuron was applied at 2.0 and $4.0 \mathrm{~kg}$ a.i. $/ \mathrm{ha}$ in September 1975, April 1977, and August 1977. At Indian Flat, tebuthiuron was applied at $4.0 \mathrm{~kg}$ a.i./ ha in October 1976 and August 1977. At Red Mountain, tebuthiuron was applied at $4.0 \mathrm{~kg}$ a.i./ ha in October 1976, May 1977, and August 1977.

Pelleted tebuthiuron containing $20 \%$ a.i. by weight was aerially broadcast at Rio Verde and Brushy Mountain. At Rio Verde, tebuthiuron was applied at 1.2 and $2.0 \mathrm{kga}$ a.i./ ha on nonreplicated 3.1-ha plots and at $4.9 \mathrm{~kg}$ a.i. $/ \mathrm{ha}$ on a 2.6-ha plot November 1977. At Brush Mountain, tebuthiuron was applied at $0.9,1.8$, and $4.6 \mathrm{~kg}$ a.i./ ha on nonreplicated 8.1-ha plots in May 1979.

\section{Plant Collections}

Foliage of shrubs, foliage and stems of a half-shrub, and foliage and culms of perennial grasses were collected each fall between 1980 and 1986. Samples were a composite of approximately equal amounts of vegetation from a minimum of 10 randomly selected plants of a species from throughout the sampled plot at each location. Foliage of shrubs was harvested by hand. Current year foliage and stems of half-shrubs were cut from the plant with shears. Grasses were cut to within $2.5 \mathrm{~cm}$ of the ground and current year top growth kept for assays. All plant materials were placed in paper bags and dried in a forced-air drier at $60^{\circ} \mathrm{C}$ for 48 hours. The dried samples were ground to pass a 40 -mesh screen, and stored at room temperature in sealed glass bottles. Plants from untreated plots were harvested to determine the recovery of tebuthiuron and its metabolites in the assays.

A total of 120 composite samples were collected. Three shrubs, 1 half-shrub, and 9 perennial grass species were collected. Plant material was not uniformly available every year because of dry summers, grazing, or dying plants. Only blue grama was collected from all 5 locations. Sideoats grama was collected from Brushy Mountain, Drake, and Rio Verde. Black grama was collected from Drake and Rio Verde. All other species were collected from single locations. Eight species were collected at Brush Mountain, 5 at Drake and Rio Verde, and 1 at Indian Flat and Red Mountain.

\section{Assays}

Tebuthiuron and its metabolites were extracted from 3-g samples taken from the composite samples and assayed following the method described by Loh et al. (1978) using a gas chromatograph equipped with a flame photometric detector. Tebuthiuron was assayed separately from its metabolites. Metabolites I and II, $N$-[5-(1,1-diemethylethyl)-1,3,4-thiadiazol-2-yl- $N$-methylurea and $N$-[5-(1,1-dimethylethyl)-1,3,4-thiadiazol-2-yl]- $N^{\prime}$-hydroxymethyl$N$-methylurea, respectively, were assayed together (Loh et al. 1978). Metabolite III, $N$-[5-(2-hydroxy-1,1-dimethylethyl)-1,3,4thiadiazol-2-yl]- $N, N^{\prime}$-dimethylurea, was assayed separately. Tebuthiuron and metabolite standards were added to untreated samples and compared to unknown samples to quantify the amounts of tebuthiuron and its metabolites with the aid of a Spectra Physics Minigrator ${ }^{1}$. Recovery of tebuthiuron added to untreated plant material ranged from 92 to $99 \%$, that of metabolites I and II 79 to $96 \%$, and that of metabolite III 70 to $79 \%$. The lower detection

\footnotetext{
Mention of tradenames does not indicate endorsement by USDA.
} 
limits were $0.1 \mu \mathrm{g} / \mathrm{g}$ of tebuthiuron and metabolites I and II, and $0.3 \mu \mathrm{g} / \mathrm{g}$ of metabolite III (Loh et al. 1978).

\section{Calculations and Statistical Analyses}

Except when discussing specific metabolites, they are reported as the combined amounts of all 3. Tebuthiuron and metabolite concentrations are reported separately, but the concentrations are summed for general comparisons because ratios of tebuthiuron to metabolites varied widely. Because data were from different trials, data were grouped and nonparametric rank sum tests comparing each observation relative to every other observation (Huntsberg and Billingsley 1981) were used to determine differences $(P=0.05)$ of combined tebuthiuron and metabolites recovered between species, soils, application rates, and years after application for side- oats and blue grama. Sideoats and blue grama were compared only when harvested at the same time from the same plots. Soils were compared by combining data from all locations and rates for sideoats grama, and then for blue grama; years after application were compared the same way. Application rates were compared for sideoats grama and then blue grama on the same soils from all locations. Data obtained from assays of soil collected from these plots at the same time plants were harvested have been reported earlier (Johnsen and Morton 1989); these data were used in regresson test to determine if the amounts of herbicide in the soil profile correlated with the concentrations of tebuthiuron plus metabolites in sideoats and blue grama.

Table 2. Concentrations of tebuthiuron and its metabolites in grasses, shrubs, and a half-shrub following tebuthiuron applications at 5 north-central Arizona locations. Samples were composites of 10 or more plants of a species from each treatment at indicated years after application.

\begin{tabular}{|c|c|c|c|c|c|c|c|c|c|c|c|c|}
\hline \multirow[b]{2}{*}{ Plant } & \multirow[b]{2}{*}{ Site ${ }^{l}$} & \multirow[b]{2}{*}{ Rate } & \multicolumn{10}{|c|}{ Years after application ${ }^{2}$} \\
\hline & & & 2 & 3 & 4 & 5 & 6 & 7 & 8 & 9 & 10 & 11 \\
\hline & & $\mathrm{kg} / \mathrm{ha}$ & $\ldots \ldots$ & $-\ldots .$. & - . - - - & $\ldots$ Teb & thiuron/s & etabolites & $\mu \mathrm{g} / \mathrm{g}-$ & $\ldots \ldots$ & $\ldots \ldots$ & $-\ldots$ \\
\hline $\begin{array}{l}\text { Grasses: } \\
\text { Black grama }\end{array}$ & $\begin{array}{l}\text { DK } \\
\text { RV }\end{array}$ & $\begin{array}{l}2.2 \\
2.0 \\
4.9\end{array}$ & $\begin{array}{l}- \\
-\end{array}$ & $\begin{array}{l}-\overline{4} / 2.2 \\
1.7 / 4.3\end{array}$ & $\overline{0.5 / 5.9}$ & $\begin{array}{l}-\overline{0.4} / 0.4 \\
0.5 / 0.3\end{array}$ & $02 . / 0.7$ & $\begin{array}{l}-\overline{3} / 0.3 \\
0.0 / 1.0\end{array}$ & $\overline{0.0 / 1.4}$ & - & $\begin{array}{l}0.0 / 0.2 \\
- \\
-\end{array}$ & - \\
\hline \multirow[t]{11}{*}{ Blue grama } & $\mathrm{BM}$ & $\begin{array}{l}0.9 \\
1.8 \\
4.6\end{array}$ & $\begin{array}{l}0.1 / 7.7 \\
-\end{array}$ & $\begin{array}{l}0.1 / 1.2 \\
0.2 / 2.8 \\
-\end{array}$ & $\begin{array}{l}0.4 / 2.0 \\
0.1 / 2.0 \\
0.8 / 2.1\end{array}$ & $\begin{array}{l}0.1 / 1.8 \\
0.1 / 2.7 \\
0.1 / 3.1\end{array}$ & - & $\begin{array}{l}-\overline{-} \\
0.0 / 0.0 \\
0.0 / 1.9\end{array}$ & - & $\begin{array}{l}- \\
-\end{array}$ & - & - \\
\hline & DK & 2.2 & - & - & - & - & - & $0.3 / 4.8$ & $0.0 / 1.4$ & $0.0 / 1.8$ & $0.0 / 1.6$ & $0.0 / 2.3$ \\
\hline & & 4.5 & - & - & - & - & $\ldots$ & $1.0 / 14.9$ & $1.0 / 4.1$ & $0.1 / 3.1$ & $0.0 / 24.5$ & $0.0 / 4.9$ \\
\hline & & 6.7 & - & - & - & - & - & - & $0.1 / 1.5$ & $0.0 / 2.6$ & $1.0 / 10.7$ & $0.0 / 2.1$ \\
\hline & IF & 4.0 & - & - & - & - & - & $0.2 / 2.6$ & $0.0 / 4.8$ & $0.0 / 2.0$ & $0.0 / 2.0$ & - \\
\hline & & 4.0 & - & - & - & - & $0.0 / 0.6$ & $0.2 / 5.2$ & $0.0 / 1.7$ & $0.0 / 0.5$ & - & - \\
\hline & RM & 4.0 & - & - & - & - & - & $0.3 / 2.6$ & $0.1 / 2.7$ & $0.0 / 5.1$ & $0.0 / 2.1$ & - \\
\hline & & 4.0 & - & - & - & - & $0.2 / 1.5$ & $0.1 / 3.6$ & $0.0 / 4.6$ & $0.0 / 2,2$ & - & - \\
\hline & & 4.0 & - & - & - & - & $0.2 / 3.3$ & - & - & $0.0 / 2.6$ & - & - \\
\hline & RV & 2.0 & - & $0.1 / 2.1$ & - & $1.1 / 3.1$ & $0.0 / 0.2$ & $0.1 / 0.6$ & $0.0 / 1.4$ & $0.0 / 0.0$ & 一 & - \\
\hline & & 4.9 & - & $2.8 / 5.8$ & - & $0.1 / 0.7$ & - & - & $0.0 / 0.4$ & $0.0 / 0.0$ & - & - \\
\hline \multirow[t]{8}{*}{ Sideoats grama } & BM & 0.9 & $0.1 / 0.1$ & $0.6 / 1.3$ & $0.3 / 2.6$ & $0.1 / 2.5$ & $0.0 / 0.3$ & - & - & - & - & - \\
\hline & & 1.8 & $0.1 / 5.6$ & $1.2 / 3.4$ & $0.4 / 1.7$ & $0.2 / 2.0$ & $0.0 / 1.9$ & $0.0 / 0.2$ & - & - & - & - \\
\hline & & 4.6 & - & - & $0.6 / 2.3$ & $0.4 / 2.9$ & $0.0 / 0.8$ & $0.0 / 1.6$ & - & - & - & - \\
\hline & DK & 2.2 & - & - & - & - & - & - & $0.2 / 2.1$ & $0.1 / 2.8$ & $0.0 / 0.2$ & - \\
\hline & & 4.5 & - & - & - & - & - & - & - & $1.2 / 4.6$ & $0.0 / 2.6$ & - \\
\hline & & 6.7 & - & - & - & - & - & - & - & $3.6 / 17.5$ & $1.7 / 21.8$ & - \\
\hline & RV & 2.0 & - & $0.2 / 1.4$ & $0.4 / 3.8$ & $0.4 / 1.5$ & - & $0.0 / 2.0$ & $0.0 / 0.7$ & $0.0 / 0.7$ & - & 一 \\
\hline & & 4.9 & - & $0.1 / 3.6$ & - & $0.1 / 1.2$ & - & $0.0 / 1.0$ & $0.0 / 0.8$ & $0.0 / 0.0$ & - & - \\
\hline Spike muhly & $\mathrm{BM}$ & 0.9 & - & - & $0.1 / 0.2$ & - & - & - & - & - & - & - \\
\hline Squirreltail & DK & 4.5 & - & 一 & - & - & - & - & $0.2 / 0.3$ & - & - & - \\
\hline Threeawn & RV & 2.0 & - & $0.2 / 4.6$ & $0.0 / 0.0$ & $0.2 / 0.7$ & - & - & - & - & - & - \\
\hline & & 4.9 & - & $0.1 / 2.0$ & - & $0.1 / 1.1$ & - & - & - & 一 & - & - \\
\hline Tobosa & DK & 2.2 & 一 & - & - & - & - & - & $0.0 / 0.2$ & - & - & - \\
\hline & & 6.7 & - & - & - & - & - & - & - & $0.4 / 4.5$ & - & - \\
\hline Weeping lovegrass & $\mathrm{BM}$ & 4.6 & - & - & - & $1.3 / 2.3$ & - & - & - & - & - & - \\
\hline Western wheatgrass & $\mathrm{BM}$ & 1.8 & - & - & $0.3 / 0.4$ & - & - & - & - & - & - & - \\
\hline \multicolumn{13}{|l|}{ Half-shrub: } \\
\hline Snakeweed & RV & $\begin{array}{l}2.0 \\
4.9\end{array}$ & - & $\begin{array}{l}6.7 / 0.4 \\
9.2 / 0.1\end{array}$ & - & - & - & - & - & - & - & - \\
\hline \multicolumn{13}{|l|}{ Shrubs: } \\
\hline \multirow[t]{3}{*}{ Skunkbush } & BM & 0.9 & $0.2 / 3.5$ & $2.0 / 1.1$ & - & $-\cdots$ & - & - & - & - & - & - \\
\hline & & 1.8 & $1.6 / 4.0$ & $1.0 / 3.4$ & - & 一 & 一 & - & - & - & - & - \\
\hline & & 4.6 & $0.3 / 0.9$ & - & - & - & - & - & - & - & 一 & - \\
\hline \multirow[t]{3}{*}{ Tubinella oak } & BM & 0.9 & $0.1 / 0.1$ & $1.6 / 0.2$ & - & - & - & - & - & - & - & - \\
\hline & & 1.8 & $0.1 / 0.8$ & $1.5 / 1.4$ & - & - & - & - & - & - & - & - \\
\hline & & 4.6 & $0.9 / 4.3$ & - & - & - & - & - & - & - & - & - \\
\hline Wait-a-minute & $\mathrm{BM}$ & 1.8 & - & - & $1.2 / 0.2$ & - & - & - & - & - & - & - \\
\hline
\end{tabular}

${ }^{1} \mathrm{Bm}=$ Brushy Mountain; DK = Drake; IF = Indian Flat; RM = Red Mountain; R V = Rio Verde ${ }_{2}-=$ not sampled 


\section{Results and Discussion}

\section{Duration}

Tebuthiuron was detected in current season growth of sideoats and blue grama 2 to 10 years after application and metabolites of tebuthiuron were detected in blue grama 2 to 11 years (Table 2). The longest tebuthiuron was detected was in sideoats grama 10 years after application of $6.7 \mathrm{~kg} / \mathrm{ha}$ at Drake. The longest tebuthiuron was detected with rates of 2.0 or less $\mathrm{kg} / \mathrm{ha}$ was in black grama and blue grama 7 years after applications at Rio Verde. But data for such application rates were limited to 0.9 and $1.8 \mathrm{~kg} /$ ha at Brushy Mountain, and $2.0 \mathrm{~kg} / \mathrm{ha}$ at Rio Verde, and sampled no longer than 6,7, and 9 years after applications, respectively (Table 2).

\section{Concentration Totals}

The highest concentration of tebuthiuron plus metabolites measured was $24.5 \mu \mathrm{g} / \mathrm{g}$ in blue grama 10 years after application of 4.5 $\mathrm{kg} /$ ha at Drake (Table 2). The highest concentrations for sideoats grama were $21.1 \mu \mathrm{g} / \mathrm{g} 9$ years and $23.5 \mu \mathrm{g} / \mathrm{g} 10$ years after application of $6.7 \mathrm{~kg} / \mathrm{ha}$, both at Drake. Of 120 samples assayed, only these 3 exceeded the $20 \mu \mathrm{g} / \mathrm{g}$ limit for tebuthiuron plus metabolites set by the Environmental Protection Agency for forage plants.

Only $4 \%$ of the 120 samples had concentration totals of $10 \mu \mathrm{g} / \mathrm{g}$ or more; $16 \%$ had $5 \mu \mathrm{g} / \mathrm{g}$ or more, and $74 \%$ had $1 \mu \mathrm{g} / \mathrm{g}$ or more (Table 2). On the other hand, no herbicide or metabolites were detected in $4 \%$ of the samples, and $26 \%$ had concentration totals of less than $1 \mu \mathrm{g} / \mathrm{g}$.

Concentration varied greatly among rates, locations, and years. Concentrations in the plants did not differ significantly with application rates $(P=0.05)$, perhaps because the herbicide was not uniformly dispersed in the soils, and the plants metabolized the herbicide. No samples exceeded $10 \mu \mathrm{g} / \mathrm{g}$ of tebuthiuron plus metabolites from applications of 4.0 or less $\mathrm{kg} / \mathrm{ha}$, and only $10 \%$ of the 80 samples at rates exceeded $5 \mu \mathrm{g} / \mathrm{g}$ (Table 2).

The trends for increased concentrations of tebuthiuron and metabolites in grasses 9 and 10 years after applications (Table 2) arc similar to that with tebuthiuron in soils on the same plots after 9,10 , and 11 years (Johnsen and Morton 1989). The increased concentrations in grasses likely represents increasing tebuthiuron available for root absorption due to long-term tebuthiuron accumulation in the soil at depths to which moisture penetrated (Johnsen and Morton 1989).

\section{Tebuthiuron}

Tebuthiuron was detected in 53 of 54 plant samples collected 5 years or less after application. A sample of threeawn (Aristida spp.) contained no detectable tebuthiuron or metabolites less than 5 years after application (Table 2). Over all, tebuthiuron was in $63 \%$ of the 120 samples assayed. The highest concentration of tebuthiuron detected was $9.2 \mu \mathrm{g} / \mathrm{g}$ in broom snakeweed [ Gutierrezia sarothrae (Pursh) Britt. \& Rusby] 3 years after application of $4.9 \mathrm{~kg} /$ ha at Rio Verde (Table 2). The highest concentrations of tebuthiuron detected in sideoats grama was $3.6 \mu \mathrm{g} / \mathrm{g} 9$ years after application of $6.7 \mathrm{~kg} / \mathrm{ha}$, and in blue grama was $2.8 \mu \mathrm{g} / \mathrm{g} 3$ years after application of $4.9 \mathrm{~kg} / \mathrm{ha}$, both at Drake. Tebuthiuron was detected in sideoats at $1.7 \mu \mathrm{g} / \mathrm{g}$ and in blue grama at $1.0 \mu \mathrm{g} / \mathrm{g} 10$ years after application of $6.7 \mathrm{~kg} / \mathrm{ha}$ at Drake (Table 2).

\section{Metabolites}

Metabolites I and II were present whenever metabolites were detected. However, metabolite III was detected in only 4 grass species, and then only in the 1984 collections. These collections represented the 5th, 7th, and 9th years after applications at Brushy Mountain, Red Mountain, and Drake, respectively. The main difference between 1984 and the other collection years was that in 1984 rainfall was almost twice the normal amounts in July and August, and above average in September. The additional growing season rainfall would increase grass growth and metabolic activity, thereby increasing metabolic decomposition of tebuthiuron in the plants. Thus, the presence of metabolite $11 \mathrm{I}$ in the 1984 collections is most likely due to growth conditions rather than duration after application.

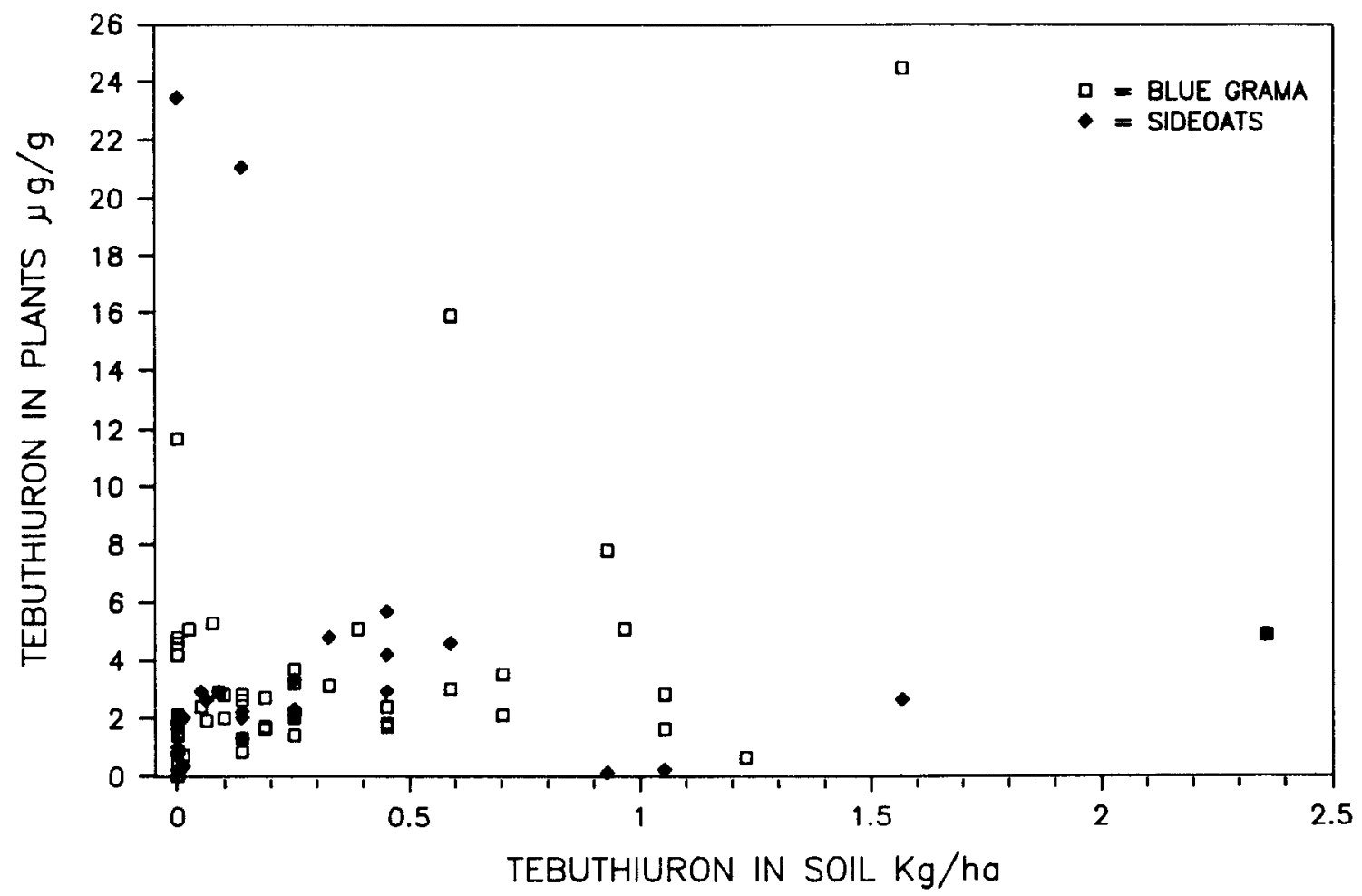

Fig. 1. Association of tebuthiuron and metabolites concentration totals in sideoats and blue grama with the amount of tebuthiuron in the soil profile. Soils data are from Johnsen and Morton (1989). 
At Brush Mountain, metabolite III was detected 5 years after application in blue grama at concentrations of $0.6,0.6$, and 1.1 $\mu \mathrm{g} / \mathrm{g}$ with rates of $0.9,1.8$, and $4.6 \mathrm{~kg} /$ ha, respectively; in sideoats grama at $1.6,0.7$, and $1.1 \mu \mathrm{g} / \mathrm{g}$ with rates of $0.9,1.8$, and $4.6 \mathrm{~kg} / \mathrm{ha}$, respectively; and in weeping lovegrass [Eragrostis curvula (Schrad.) Nees] at $0.3 \mu \mathrm{g} / \mathrm{g}$ with a rate of $4.6 \mathrm{~kg} / \mathrm{ha}$. At Red Mountain, metabolite III was detected 7 years after application in blue grama at a concentration of $0.5 \mu \mathrm{g} / \mathrm{g}$ with both $4.0 \mathrm{~kg} / \mathrm{ha}$ applications. At Drake, metabolite III was detected 9 years after application in blue grama at concentrations of $1.3,1.2$, and $2.0 \mu \mathrm{g} / \mathrm{g}$ with rates of 2.2 , 4.5 , and $6.7 \mathrm{~kg} / \mathrm{ha}$, respectively; in sideoats grama at $2.7,1.3$, and $5.1 \mu \mathrm{g} / \mathrm{g}$ with rates of $2.2,4.5$, and $6.7 \mathrm{~kg} / \mathrm{ha}$, respectively; and in tobosa grass [ Hilaria mutica Benth.] at $1.8 \mu \mathrm{g} / \mathrm{g}$ with the rate of 6.7 $\mathrm{kg} / \mathrm{ha}$.

\section{Sites}

Concentrations in sideoats and blue grama were independent of the total amount of tebuthiuron in the soil profile reported by Johnsen and Morton (1989) (Fig. 1). This independence might be expected as the herbicide would not be uniformly distributed in the soil profile, nor would roots be distributed uniformly in the soil, and the plants metabolize the herbicide. The plants may metabolize the herbicide rapidly enough to prevent maximum accumulation in the plant and, therefore, not reflect the amount of tebuthiuron in the soil profile.

Whenever it was detected in the soil, tebuthiuron or its metabolites were detected in current season growth of the grasses. The herbicide was found in the grasses but not in the soil in 25 samples and was not detected in the soil when not detected in the grasses (Fig. 1). Plants seem to be very efficient in accumulating tebuthiuron present in small amounts in the soil, and thus might be used to determine if tebuthiuron is in the soil, but not the amount present. Although there was no significant difference $(P=0.05)$ between soils, only loam and sandy loam soils had grasses which contained no tebuthiuron or metabolites (Tables 1 and 2).

\section{Species Differences}

Generally, there was little difference between concentration totals in sideoats and blue grama collected at the same time from the same plot (Table 2). Differences could occur because the shallower-rooted blue grama could accumulate herbicide soon after application before it leached deep into the soil, while the deeper-rooted sideoats grama could accumulate more of the herbicide when it was leached more deeply into the soil.

Grasses contained less tebuthiuron than metabolite (Table 2), and did not accumulate phytotoxic amounts of tebuthiuron. Shrubs and the half-shrub often contained more tebuthiuron than metabolites, and accumulated phytotoxic amounts of tebuthiuron, dying within 4 or 5 years of treatment. These observations agree with those of Martin and Morton (1981).

\section{Conclusions}

This study illustrated that tebuthiuron and its metabolites may be detected in current growing season foliage more than a decade after application in a semiarid environment. Plants were not sampled beyond 11 years after application. How long after application tebuthiuron or its metabolites can be detected in plants under semiarid conditions remains uncertain. Generally, concentrations of tebuthiuron and its metabolites in plants varied, but were low, seldom exceeding the limits set by the Environmental Protection Agency for forage, and then only with application rates of 4.5 or more $\mathrm{kg} / \mathrm{ha}$. Thus, normal applications of pelleted tebuthiuron at rates of $2 \mathrm{~kg}$ or less a.i./ ha on rangelands did not exceed the established tolerance level for tebuthiuron for grazing animals.

\section{Literature Cited}

Baur, J.R., and R.W. Bovey. 1975. Herbicidal effects of tebuthiuron and glyphosate. Agron. J. 67:547-533.

Biondini, M., R.D. Pettit, and V. Jones. 1986. Nutritive value of forages on sandy soils as affected by tebuthiuron. J. Range Manage. 39:396-399.

Bovey, R.W., F. Bumett, R.E. Meyer, C. Richardson, and A. Loh. 1978. Persistence of tebuthiuron in surface runoff water, soil, and vegetation in Texas blacklands prairie. J. Environ. Qual. 7:233-236.

Bovey, R.W., H. Hein Jr., R.E. Meyer. 1984. Effect of herbicides on the production of common buffel grass (Cenchrus ciliaris). Weed Sci. 32:8-12.

Bovey, R.W., R.E. Meyer, and H. Hein, Jr. 1982. Soil persistence of tebuthiuron in the claypan resource area of Texas. Weed Sci. 30:140-144.

Clary, W.P., S. Goodrich, and B.M. Smith. 1985a. Response to tebuthiuron by Utah juniper and mountain big sagebrush communities. J. Range Manage. 38:56-60.

Clary, W.P., S. Goodrich, and B.M. Smith. 1985b. Response of broom snakeweed to application of tebuthiuron. USDA, Forest Serv. Intermountain Forest and Range Exp. Sta. Res. Note INT-350.

Elanco, Products Company. 1983. Gralan-Technical manual. Eli Lilly and Co. Indianapolis.

Emmeric, W.E., J.D. Helmer, K.G. Renard, and L.J. Lane. 1984. Fate and effectiveness of tebuthiuron applied to a rangeland watershed. J. Environ. Qual. 13:382-386.

Garcia, J.D., and S.C. Lee. 1979. A hypothesis on cycling of tebuthiuron, p. 39-40. In: Noxious Brush and Weed Control Res. Highlights 1979. Tex. Tech. Univ., Lubbock, Texas 10:39-40.

Herbel, C.H., H.L. Morton, and R.P. Gibbens. 1985. Controlling shrubs in the arid southwest with tebuthiuron. J. Range Manage. 38:391-394.

Huntsberger, D.V., and P. Billingsley. 1981. Elements of statistical inference. 5th ed. Allyn and Bacon, Inc., Boston.

Ibarra-Flores, F.A. 1984. Brush control, forage production and tebuthiuron residues in soils and plants at four creosotebush (Larrea tridentata) sites in the Chihuahuan and Sonoran Deserts. MS Thesis. School of Renewable Natural Resources, Graduate College. Univ. Arizona.

Ibarra, F.A., and H.L. Morton. 1984. Tebuthiuron residues in Chihuahuan and Sonoran desert soils. Proc. Western Soc. Weed Sci. 37:113-127.

Johnsen, T.N., Jr., and H.L. Morton. 1989. Tebuthiuron persistence and distribution in some semiarid soils. J. Environ. Qual. 18:(in press).

Loh, A., S.D. West, and T.D. Macy. 1978. Gas chromatographic analysis of tebuthiuron and its metabolites in gras, sugarcane, and sugarcane by-products. J. Agr. Food Chem. 26:410-413.

Martin, R.D., and H.L. Morton. 1981. Tebuthiuron absorption, translocation and metabolism by rangeland plants. Abstr. Weed Sci. Amer. p. 7. Abstr. 1981 Meeting Weed Sci. Soc. Amer. Feb. 17-19, 1981. Las Vegas, Nev.

Masters, R.A., and C.J. Scifres. 1984. Forage quality responses of selected grasses to tebuthiuron. J. Range Manage. 37:83-87.

McDaniel, K.C., and J.F. Balliette. 1986. Control of big sagebrush (Artemisia tridentata) Weed Sci. 34:276-280.

McNeil, W.K., J.F. Stritzke, and E. Basler. 1984. Absorption, translocation, and degradation of tebuthiuron and hexazinone in woody species. Weed Sci. 32:739-743.

Meyer, R.E., R.W. Bovey, L.F. Bouse, and J.B. Carlton. 1983. Response of live oak (Quercus virginiana) and understory vegetation to herbicides. Weed Sci. 31:639-647.

Pettit, R.D. 1979. Effects of picloram and tebuthiuron pellets on sand shinnery oak communities. J. Range Manage. 32:196-200.

Scifres, C.J., and J.L. Mutz. 1978. Herbaceous vegetation changes following applications of tebuthiuron for brush control. J. Range Manage. 31:375-378.

Scifres, C.J., J.L. Mutz, and W.T. Hamilton. 1979. Control of mixed brush with tebuthiuron. J. Range Manage. 32:155-158.

Scifres, C.J., J.R. Scifres, and M.M. Kothmann. 1983. Differential grazing use of herbicide treated areas by cattle. J. Range Manage. 36:65-69.

Sosebee, R.E., W.E. Boyd, and C.S. Brumly. 1979. Broom snakeweed control with tebuthiuron. J. Range Manage. 32:179-182.

Steinert, W.G., and J.F. Stritzke. 1977. Uptake and phytotoxicity of tebuthiuron. Weed Sci. 25:390-395.

Whitson, T.D., and H.P. Alley. 1984. Tebuthiuron effects on Artemisia spp. and associated grasses. Weed Sci. 32:180-184. 